in a few years, these become reduced to a few, such as perennial ryegrass, wild white clover, etc.; exceptions to this sometimes come to light, such as when Percival observed that, in the Thames Valley, all the species of plants sown were still found after nineteen years. In the ley studied at Rothamsted, the ryegrass, cocksfoot, timothy, rough-stalked meadow grass and wild white clover formed the overwhelming bulk of the herbage after eight years. It is interesting to contrast some features of these results with those found by Alun Roberts at a number of centres in Wales, where the rainfall is higher, and where there is hard winter grazing by sheep. At Rothamsted, cocksfoot, and particularly timothy, survived much better than at the Welsh centres. Again, in the west, Italian ryegrass had completely disappeared at every centre in three years, while at Rothamsted this variety proved unexpectedly persistent, contributing largely after eight years; it must be assumed that this persistence was due to self-seeding. The Rothamsted experiments are important for large tracts in the drier parts of Fingland, where economic conditions have forced many to put down land to grass.

The experiments on the composition of ryegrass are of particular interest in view of the position regarding the various methods of grass conservation. The high proportion of fructosan, which is soluble in cold water, found in spring grass when the panicle emerges, and the decrease in this substance on further maturity, indicates that research in this direction may throw important light on such questions as losses in conserving young and more mature grass by various methods, and the relative values at different times of the year of pasture grass having similar chemical composition when expressed by the conventional method.

Experiments on the relation of cultivation to crop yield have been in progress since 1926, these being concerned with a study of the effects of the standard operations, and with a comparison of standard methods with rotary cultivation. There is a considerable body of evidence from other countries that yields are not increased either by extra or deeper cultiva. tion above a certain minimum well below what British farmers would accept, and eleven years experiments on heavy soil at Rothamsted and on light soil at Woburn tend to confirm this. Rotary cultivation, which produces a tilth in one operation, has given no harmful results when carried out on the same land year after year, provided that-for certain cropsit is done sufficiently deeply.

Other sections of the report, such as those dealing with the work of the Fermentation Department and of the Departments of Fungicides and Insecticides, and also of Entomology, are equally important because of the amount of valuable information contained in them.

\title{
Display and Reference Exhibits in Museums
}

\section{By Samuel G. Gordon, Department of Mineralogy, Academy of Natural Sciences of Philadelphia}

$\mathrm{T}$ HE new mineral gallery of the Academy of Natural Sciences of Philadelphia contains seven sections devoted to educational exhibits, the William S. Vaux Collection, Pennsylvania minerals, the fluorescent minerals, meteorites, gem stones, and special exhibits (radioactivity, new accessions, loan collections, etc.)

Frameless cases, virtually glass envelopes (described in the Museums Journal, November 1936) were designed in which the plate-glass is supported by a minimum of metal. Such construction was found possible in large wall cases, table cases, floor cases and pedestals, with the result that visitors are less 'case-conscious'. The educational exhibits (What is Geology ? What is a Mineral ? What is a Crystal ? The Interior of the Earth, etc.) are in wall cases lined with black suède-like paper which gives the incisiveness of a blackboard sketch. The labels, a tersely written sequence, are combined with the illustrative material (rigidly selected specimens, charts, maps, transparencies, models, instruments, etc.) in a layout in which lines, designs, colour, and other symbolic devices are used to develop a logical continuity. All other lines, arbitrary designs, meaningless colour, coarse textures, hardware, supporting accessories, ornamentation and distracting effects are avoided.

Less than 10 per cent of the minerals of the Academy collections are shown in the systematic series, about half in wall cases, and the rest in high table cases. Care was taken that each individual specimen, shown against black velveteen, was set up to the best advantage (four specimens took two hours apiece for this operation). Supporting means (mostly glass tripods) are unobtrusive. The green colour of glass shelves was found to be due to total reflection (within the plates) of the back edges; the colour was eliminated by painting the back edges black. Labels were printed on plastocele (cellulose acetate) with a lino-scribe, a device which uses printers' type and cuts. There is also an index with cross references to the minerals. Lighting (outside the cases) is concealed, and unobtrusive valances were used at strategic points in the wall cases to eliminate reflections.

The fluorescence exhibit (the first in America, following soon after that in the British Museum (Natural History)) is at the turning-point of the gallery. When reopened, it will be set in operation by the visitor passing a pair of photo-electric cells, and the automatic cycle (electric lights, ultra-violet lamps, darkness) will be synchronized with a fourminute record explanatory of the phenomena.

The focal point of the next section is another educa. tional layout: "What are meteorites?" Elaborate series of cut gemstones, jades, birth-stones, ormamental stones are shown in the succeeding bay. The last section includes an exhibit of radioactivity, in which the story of its discovery precedes a demonstration using an ionization chamber connected with a circuit terminating in a neon lamp which flashes as gamma radiation enters the chamber. 
Thus modern technical resources are being used to make exhibits educational and to stimulate interest in natural history. But what about the many specimens of which the rarity, obscure character, or specialized interest do not make it feasible to give them expensive display space ? How are these to be made available to the serious student? What is to happen to the many specimens eluttering up museum cases when these are relegated to storage cabinets ?

It is probable that the answer will be found in the development of reference museums. We have all admired the efficient organization of libraries, where staffs have been trained in the cataloguing and care of books, and their preservation in fire-resisting structures. The huge bulk of accumulated natural history specimens in many of the older museums presents a storage problem. With the gradual extinction of many species of wild life, the growing scarcity of others, and the increasing difficulties of collecting, it is essential that what we already have be assured permanent preservation and greater accessibility to students.

Such collections could be compactly stored in metal cabinets in vermin-proof, fire-resisting library. stack-like structures. Specially trained curators could receive, prepare, catalogue, place and care for the specimens received by the museum. The distribution of specimens to research workers in their own and to other institutions, and of loan collections of duplicates to schools, would be in their hands. No small part of their activity would be to bring out of the stack, for examination at close hand, any specimen desired by a serious student.

An experiment in this direction will soon be made by the Mineralogical Department of the Academy. Visitors will be advised that any specimens they desire to see, if not on exhibition, will be placed by a member of the staff in a special, well-lighted case for their examination.

\section{The German North Atlantic Expedition*}

$\mathrm{H}^{2}$ AVING almost completed their examination of the data brought home from the South Atlantic Ocean by the Meteor in 1925-27, German oceanographers have set out to make a thorough investigation of the North Atlantic, and as the result of a conference between the Commander-inChief of the Navy, the council of the Deutschen Wissenschaft and the director of the Institut für Meereskunde, the German North Atlantic Expedition has been organized.

The plan of the new expedition is to complete the network of modern oceanographical observations over the Atlantic Ocean, linking up the work of the Meteor in the south with her subsequent investigations in Iceland and Greenland waters, and with the work of the American Marion and Atlantis expeditions in the Davis Strait and the western North Atlantic. The area to be covered extends from $15^{\circ} \mathrm{N}$. to $64^{\circ} \mathrm{N}$. between the west coast of Europe and Africa and a line from the West Indies to Nova Scotia.

The main objects are the study of the physicochemical structure of the sea, and meteorology. It is hoped that a large number of scientific and practical problems, many of them connected with the Gulf Stream, will be solved, and Prof. A. Defant, who is directing the work, is confident that information likely to be of material assistance in long-range weather forecasting will be obtained.

The Meteor, now re-engined as a motor-vessel with a cruising radius of 9,000 miles at an average speed of 12 knots, is to be used, and the Institut für Meereskunde, the Deutsche Seewarte, the Marine Observatories of Wilhelmshaven and Kiel, and the State Meteorological Department, are co-operating with the Navy. The whole project is not to be accomplished in one commission, but by a number of shorter voyages.

The first voyage, partly a trial cruise, and mainly

- "Bericht über den ersten Teil der Deutschen Nordatlantischen Expedition des Forschungs- und Vermessungsschiffes Meteor, Februar bis Mai, 1937", Von A. Defant. Sonderausgabe aus den Sitzungsberichten der Preussischen Akademie der Wissenschaften, Phys.-math. Klasse, 19 (1937). an addition to the original programme, was started in February and completed in May of last year. The region from $10^{\circ} \mathrm{N}$. to $28^{\circ} \mathrm{N}$. between the African coast and $30^{\circ} \mathrm{W}$. was examined; about seventy stations were worked at 60 -mile intervals on six east-to-west lines, half of them falling between the African coast and the Canary and Cape Verde Islands. At each of the inshore stations hourly observations were made over a period of 60 hours, and one series of current observations over a period of 48 hours was made with the ship anchored in deep water. Six oceanographers, two meteorologists and two magneticians were carried, and the officers and crew numbered 121 .

Only a very preliminary account of the results is available, but it is clear that much important information has been gained. The whole of the coastline of this part of Africa is marked by upwelling, and although the water comes to the surface from relatively shallow depths, the surface temperatures may be $5^{\circ}$ or $6^{\circ} \mathrm{C}$. colder than those farther offshore. The region also has a rich plankton population. The continuous hourly observations reveal changes of very short period, and show that the conditions in the thermocline at a depth of 25-60 metres respond very quickly to changes at the surface. The chemical work included determinations of silica, phosphate and nitrite.

A large number of observations were made on the upper-air currents, 209 balloons being followed by the new radio-ranging method, which seems much better adapted for work in an unsteady ship than the usual theodolite method. The nautical staff carried out an extensive programme of echo-sounding, and made researches into the reliability of modern instruments and methods of fixing positions at sea. Magnetic observations were made in the Canary and Cape Verde Islands.

During the three and a half months voyage, much was accomplished, and it is evident that the investigation of the greater part of the North Atlantic Ocean by similar methods will produce most important results.
G. E. R. D. 